\title{
Technè
}

La science au service de l'histoire de l'art et de la préservation des biens culturels

48 | 2019

Les couleurs de l'Antique

\section{Oplontis, 79 A.D.: colours on marble furnishing from the Villa of Poppaea}

Oplontis, an 79 : les couleurs sur la décoration en marbre de la villa de Poppée

\section{Antonella Bonini, Susanna Bracci, Paolo Liverani, Giovanni Bartolozzi, Roberta lannaccone, Sara Lenzi and Donata Magrini}

\section{OpenEdition}

\section{Journals}

Electronic version

URL: https://journals.openedition.org/techne/2482

DOI: $10.4000 /$ techne.2482

ISSN: 2534-5168

\section{Publisher}

C2RMF

\section{Printed version}

Date of publication: 31 December 2019

Number of pages: 90-99

ISBN: 978-2-11-152831-4

ISSN: 1254-7867

\section{Electronic reference}

Antonella Bonini, Susanna Bracci, Paolo Liverani, Giovanni Bartolozzi, Roberta lannaccone, Sara Lenzi and Donata Magrini, "Oplontis, 79 A.D.: colours on marble furnishing from the Villa of Poppaea", Technè [Online], 48 | 2019, Online since 01 July 2021, connection on 02 April 2022. URL: http:// journals.openedition.org/techne/2482 ; DOI: https://doi.org/10.4000/techne.2482

This text was automatically generated on 2 April 2022.

La revue Technè. La science au service de l'histoire de l'art et de la préservation des biens culturels est mise à disposition selon les termes de la Licence Creative Commons Attribution - Pas d'Utilisation Commerciale - Pas de Modification 4.0 International. 


\section{Oplontis, 79 A.D.: colours on marble furnishing from the Villa of Poppaea}

Oplontis, an 79 : les couleurs sur la décoration en marbre de la villa de Poppée

Antonella Bonini, Susanna Bracci, Paolo Liverani, Giovanni Bartolozzi, Roberta lannaccone, Sara Lenzi and Donata Magrini

\section{Introduction}

1 The archaeological site of the Poppaea's Villa in Oplontis ${ }^{1}$, today Torre Annunziata, was identified at the end of the 16th century, when Domenico Fontana directed the project for the Sarno Channel's building. The Count of Sarno and his heirs began the Channel works, in order to bring water from the river's springs to their mills in the area of the Real Fabbrica d'Armi and around the modern harbour. The Channel was set directly on the Roman villa's structures and used some of them on the seafront side, as shown by recent archaeological research. 
Fig. 1. Neo-Attic bell crater with Waffentanzer (inv. 71406)

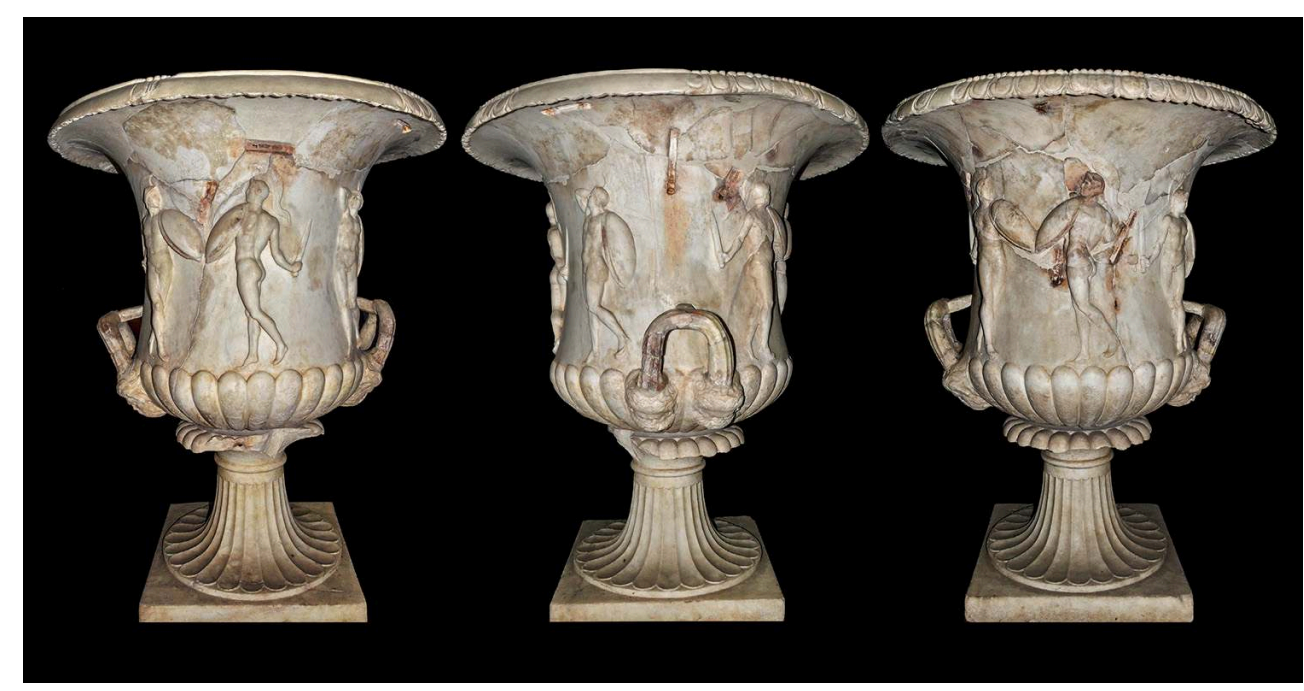

(C) ICVBC-CNR.

2 The Borbonic Government began the first archaeological excavation near the Sarno Channel. In 1785, the military architect Francesco La Vega wrote about "the ancient buildings near Torre Annunziata, [...] These buildings are inside a hole in the ground, whose opening is over the Channel used for the water supply for the Real Fabbrica d'Armi e Polveriera2". He noticed also that the excavations were stopped "because of the Mofeta (a poisonous gas in high concentration) coming from the ground". Then fifty years went by before we hear again about searching for antiquities. Excavation started anew in 1839 "in order to find the antiquities that are most-likely buried there". An open-air pitch was dug as an entrance for some underground tunnels. Digging went on, with some administrative problems, during 1839 and until August 1840, when Minister Santangelo officially approved the proposal of the General Superintendent and Museum Director Francesco Maria Avellino for the acquisition of the Mascatelle property, despite the scarceness and low value of the findings. Thus the site was preserved from modern urbanization.

3 After these events, the excavation was abandoned for over a century. In 1962, a committee of local enthusiasts, the "Friends of Oplontis", forced the Soprintendenza and the Italian Government to re-open (in 1965) the Oplontis site, with results clearly visible nowadays. The excavations, directed firstly by Amedeo Maiuri and then by Alfonso De Franciscis, were carried out by Stefano De Caro. The extraordinary findings led to a second public funding from the Cassa del Mezzogiorno in 1974. Ten years of non-stop excavations led to unearth a building with 90 rooms, covering a surface of $10000 \mathrm{~m}^{2}$, part of a bigger complex whose northern, eastern and southern limits lay under modern buildings, while the western limit is under the Borbonic Real Fabbrica d'Armi.

4 The Villa is traditionally considered as one of Poppaea Sabina's imperial properties. Recent excavations confirmed that the Villa was built on a high cliff overlooking the Gulf; a system of porticoes and terraces with belvedere, gardens on different levels and a cryptoporticus, connected it to the sea. The older part of the Villa, built around the central decades of the 1st century B.C., was organized around a Tuscanic atrium, with a wonderful second style decoration; at the mid of the 1st century A.D., the eastern 
quarter was added. This new quarter was organized around a pool and was decorated mostly with fourth style paintings. The Villa also had an area devoted to the processing and storage of the agricultural products, on the southern part.

The main feature of the Villa is the abundance of gardens, either real or painted thirteen all together. The actual gardens were reconstructed by Wilhelmina Jashemski ${ }^{3}$ and reveal a complex link with the villa's architecture, with a research for perspective axes, symmetries and scenographic backgrounds.

Nineteen statues of different dimensions were found in the Villa (fig. 2). The presence of fragments, pedestals and supports, however, led to the hypothesis of a larger amount of sculptures. Among these nineteen sculptures, six were used as fountainheads: four Centaurs, a Boy with a duck and a crater. The reconstruction of the original display of the sculptures is particularly difficult, as some of them already had been moved in the Roman age. The Centaurs and the Boy with a duck were indeed found in portico 33, as well as the Venus statue which was in room 35 . The reason for such a situation was probably the need of storage for these sculptures, before the end of the renovation works in the villa, after the earthquake of 62 A.D.

Fig. 2. Plan of locations of sculptures found in Villa A (from Gazda, Naglak, 2016, p. 137, fig. 13.2)

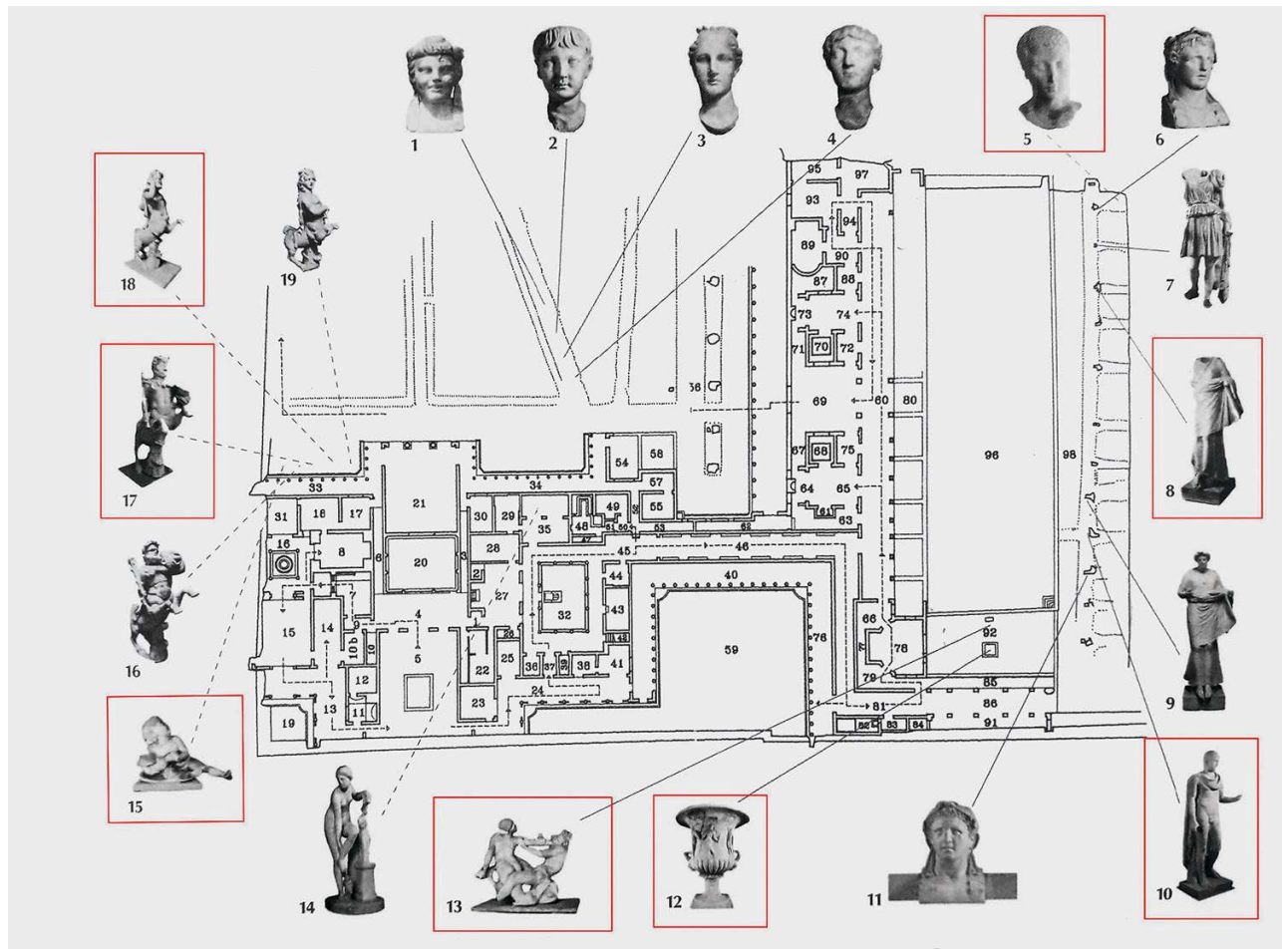

The red rectangles indicate the sculptures considered in this paper. Graphic elaboration by R. lannaccone.

7 Stefano De Caro ${ }^{4}$ hypothesized that the four Centaurs were set originally at the centre of the rear garden and on the main perspective axis, generated from the big Tuscanic atrium. On oblique paths were set four Herms with the portraits of a woman and a boy, and the head of two deities, Aphrodite and Dionysus as a child. The Boy with the duck was probably placed in the peristylium servile, underneath a big chestnut tree. It is not possible to identify the original placement of the sculpture of Venus; Elaine Gazda suggests that the statue was in one of the apsidal rooms facing the pool ${ }^{5}$. 
8 The eastern garden with the great pool ( $17 \times 62$ metres) preserved the largest amount of sculptures. Along the southern side of the pool were placed a group with Satyr and Hermaphrodite and a great crater with "Waffentanzer" (armed dancers). The crater was located on the axis of the diaeta and used as a fountainhead. Thirteen bases were found along the eastern side of the pool. Another one is probably buried under the pyroclastic flow. Some sculptures were found near the bases. Beginning from the northern part, next to the third, fourth and fifth bases, were found a head of Herakles, a female statue with a chiton and a Nike. After four empty bases, there is the same sequence: Nike male statue (an Ephebe) - another Herakles' head. The head of a boy was found between the third and the fourth base. Every sculpture was placed aligned with the trunk of the tree behind it, in order to create a natural counterpart of the colonnade on the opposite side. If the meaning of the Nikai and Herakles' heads is well-known, the identification of the Ephebe and of the female figure is more controversial. Moormann ${ }^{6}$ identifies them as the divine couple Apollo/Artemis, De $\mathrm{Caro}^{7}$ as the couple of heroes Ephebe/Amazon or Atalanta. Elaine Gazda ${ }^{8}$ adds a further identification of the Ephebe as Ippomene and hypothesizes that the little Venus sculpture was placed in front of the couple of heroes. So the passers-by could remember immediately the famous myth by Ovid?.

9 De Caro considers this garden as a Greek-style gymnasium, offering young people a place for athletic exercises under the protective gaze of deities and heroes.

10 Colour vestiges kept on these sculptures were already described in 1987 by De Caro ${ }^{10}$. For example, he could see on the crater a golden radiating crown on the warriors' shields ${ }^{11}$, red on warriors' helmets and blue on their swords; red and yellow were recognized on the little sculpture of Venus ${ }^{12}$; red was identified on a marble fragment with a $\mathrm{crab}^{13}$. This paper presents preliminary results of the non-invasive analyses carried out on eight sculptures ${ }^{14}$ (Boy with a duck ${ }^{15}$, a Nike ${ }^{16}$, Ephebe ${ }^{17}$, the crater ${ }^{18}$, two Centaurs $^{19}$, a portrait of a boy ${ }^{20}$, Satyr and Hermaphrodite ${ }^{21}$ ) and two marble fragments (inscription ${ }^{22}$ and a crab ${ }^{23}$ ).

\section{Scientific study of the polychromy}

\section{Experimental}

11 The analyses on the artefacts were carried out in situ by using non-invasive portable techniques. The well-established protocol $^{24}$ considers a first recognition with multispectral photographic techniques, especially ultraviolet fluorescence (UVf), visible (Vis) and visible-induced luminescence (VIL) photography. For the investigation, two cameras were used: a Canon EOS 7D with a resolution of 18 Megapixel and a modified Canon EOS 400D with a resolution of 10.10 Megapixel. Both cameras mounted a Canon EFS 18-135 mm f/3,5-5,6 IS lens with different filters on varying of every photographic technique applied. Different filters were applied also on the two flashes Quantum Qflash T5dR thus providing the proper radiation.

12 According to the results of multispectral imaging, points were chosen to be analysed by using portable X-ray fluorescence spectroscopy (XRF) and Fiber optics reflectance spectroscopy (FORS). All the points measured were documented with a portable optical microscope. XRF spectra were acquired by using a Tracer III SD by Bruker with rhodium anode. All the points were analysed with the following working parameters, 
$40 \mathrm{KV}-12 \mu \mathrm{A}$. FORS spectra were acquired through an Ocean Optics (mod. HR2000) spectrometer with the range of $390-800 \mathrm{~nm}$ and a measure head configuration of $2 \times 45^{\circ} /$ $0^{\circ}$. As white reflectance reference a Spectralon standard ( $99 \%$ of reflectance) was used.

The analysed statues were located in two different places. Some of them (Boy with a duck, the Centaur with a club and a crater, female Centaur with a club and a fawn on her shoulder, Nike and Ephebe) were in Palazzo Criscuolo in Torre Annunziata as part of an exhibition, while the others (Neo-Attic bell crater with Waffentanzer, a fragment of a marble slab with an inscription, a base with a crab and portrait of a boy) were stored in the storeroom in Poppea's Villa.

The last statue analysed - Satyr and Hermaphrodite - returned from an exhibition in New York only one week before the presentation of the results at the Round Table, therefore only some preliminary analyses have been done ${ }^{25}$.

\section{Results}

The first statue discussed is the Boy with a duck. A few very small traces of Egyptian blue on the duck and on the boy's plait were identified. The ultraviolet fluorescence shows only a weak yellow area under the wing of the duck. This fluorescence seems related to a degraded organic material but it is not possible, with such techniques, to distinguish between a past restoration, the residues of an original material or something absorbed from the burial ground.

Both statues portraying Centaurs do not show any evidence of colours on the surface ${ }^{26}$. In the ultraviolet fluorescence images, the male centaur shows some residues of an organic material on some areas. The blue fluorescence usually may suggest the presence of a modern material, but even in that case the techniques used cannot provide any further information about the type of material. On the hand holding the club, reddish/brown traces are visible. In the ultraviolet image of the area, a yellow fluorescence appears and the reddish/brown traces totally absorb the ultraviolet radiation. Due to their distribution on the surface and the nature of the traces, it is not clear if they are intentional traces of painting or just a residual deposit of earth.

17 In the female centaur, archaeologists pointed out the waxy appearance of some curls on the nape and the possible presence of some organic material on the surface. Observing the ultraviolet images, no difference is visible between the marble areas with waxy appearance and normal texture and no remarkable fluorescence appears. This means that, most probably, the aspect is related to some alteration of the marble which occurred during the eruption. Ahead, on the face, a light yellow fluorescence is visible. It follows the integrated parts and it is the effect of the adhesive used for the filling.

The Nike shows interesting traces of polychromy more or less visible to the naked eye. Traces of Egyptian blue have been found on the chest, especially on the belt, which crossed the chest. But the most visible traces of Egyptian blue are on the himation, just under the left arm. Here extensive residues have been found (fig. 3). 
Fig. 3 a-c. Nike (inv. 73520)

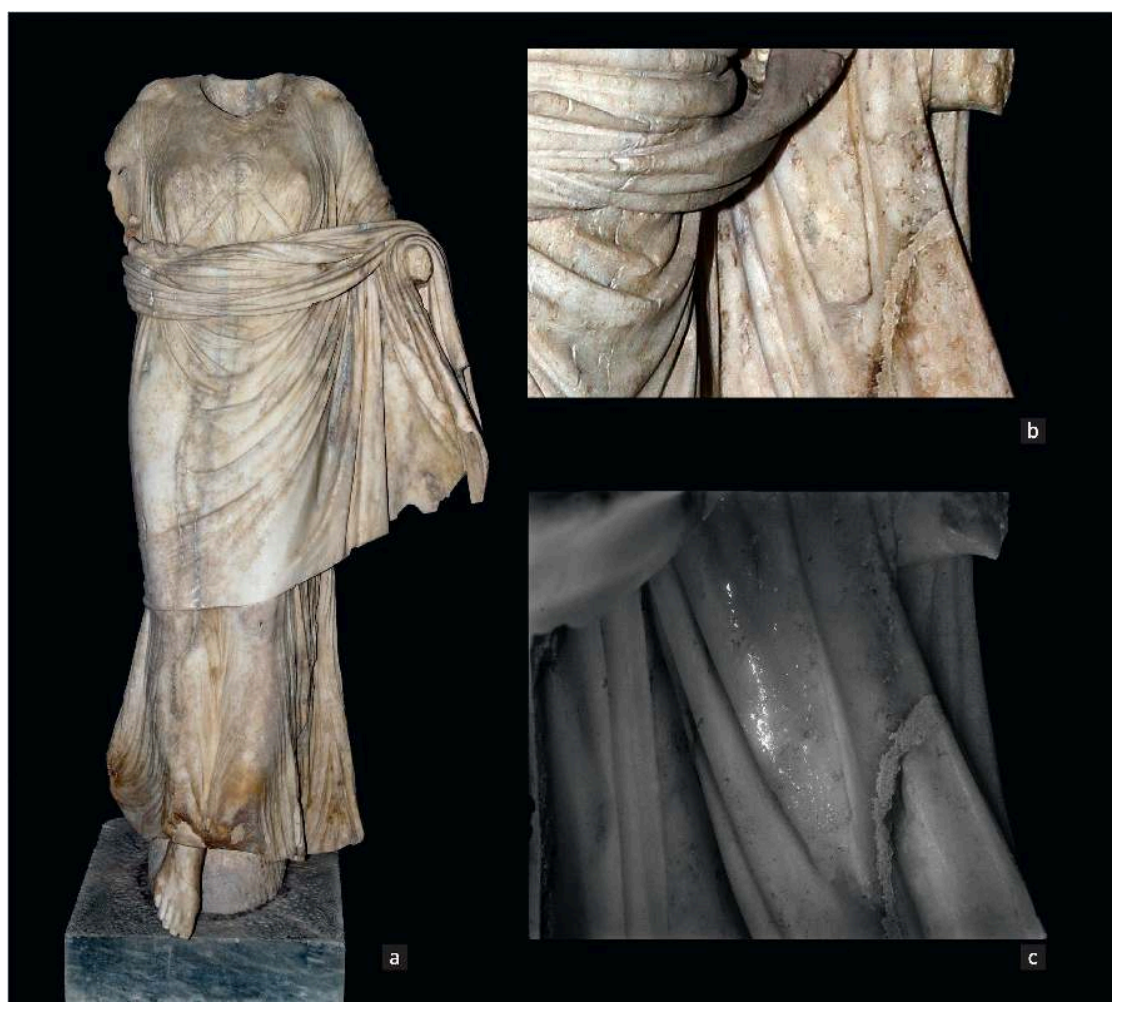

a. Detail of traces of Egyptian blue; b. Visible image; c. VIL image.

(c) ICVBC-CNR.

19 The amount and the position of the traces on the himation made it possible to conduct analyses with both punctual techniques. XRF shows the presence of copper, while calcium, iron and strontium are also visible in the background spectrum of the white marble. Likewise the FORS spectrum acquired on the same area shows a large similarity with the reference of a spectrum of Egyptian blue already published ${ }^{27}$.

The ultraviolet fluorescence on the Ephebe reveals a bright yellow fluorescence over the ensemble of the mantle's surface. In addition to this, traces of red are spread on the surface and they are visible to a close observation (fig. 4 a-c). 
Fig. 4 a-c. Ephebe (inv. 72818)

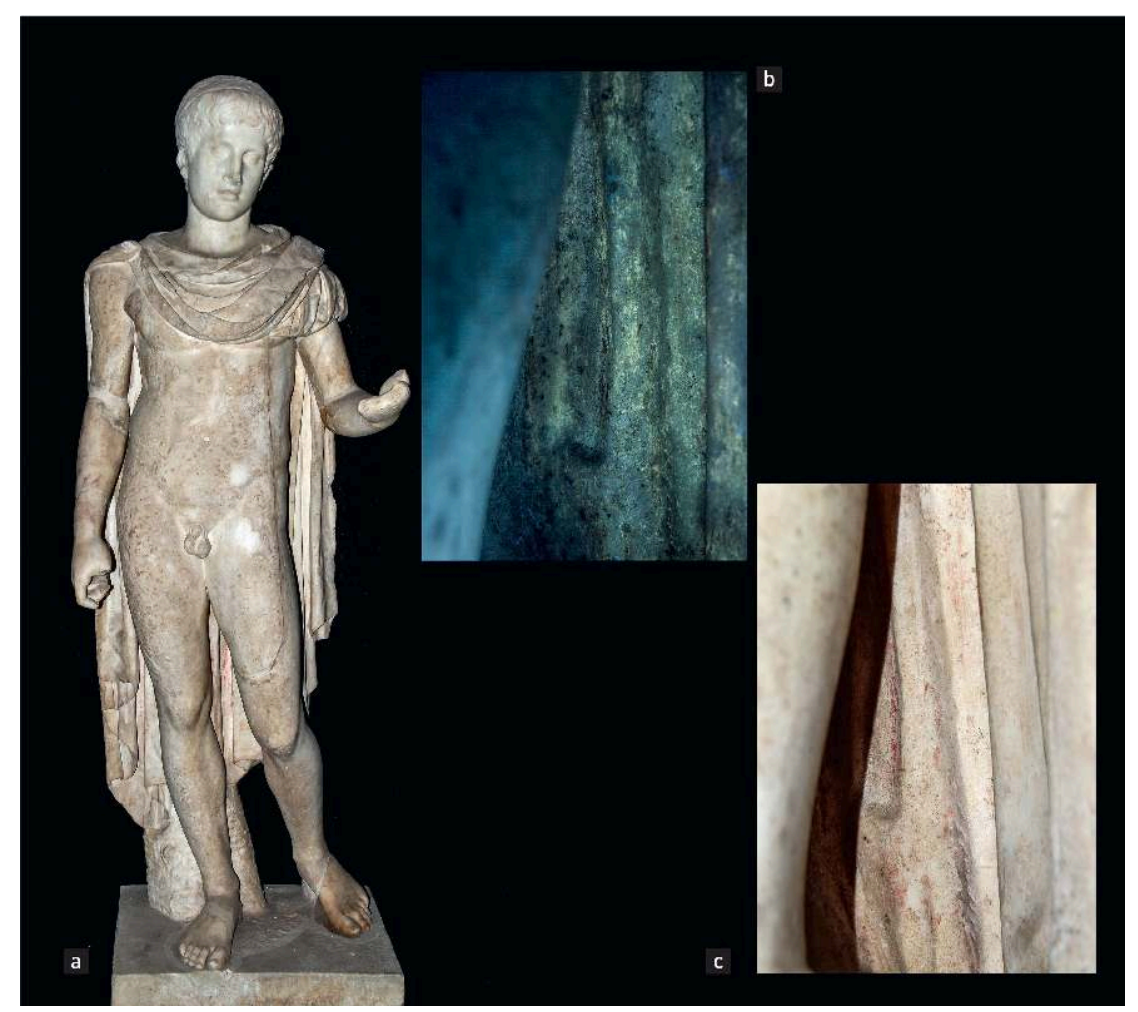

a. Detail of yellow fluorescence and of red traces on the mantle; b. UVf image; c. Visible image. (c) ICVBC-CNR.

21 On the left side of the statue, the yellow fluorescence is less diffuse than on the right side and it is visible only in the areas protected against the weather. VIL shows a few spots of Egyptian blue on the mantle, but the amount is not enough to speculate about its function in that area.

Due to the position of the traces remaining on the mantle, most of them in the recesses of deeply carved folds, only one point could be measured by XRF and FORS. It shows the presence of cinnabar in correspondence with the red traces. In the XRF spectrum of the measured point counts for lead are also visible. It was assumed that the yellow fluorescence indicates the presence of a lead compound on the surface.

As mentioned before, part of the analysed sculptures are in the archaeological storage close to the Poppea's Villa, and among these, there is the Neo-Attic bell crater (fig. 5). This crater shows some residual drawings on the shields of the warriors (fig. 6). Ultraviolet fluorescence photography helped to enhance the drawing, but XRF does not show any meaningful element, therefore the pigment used could be organic, such as an organic black. Also the FORS measurement couldn't be decisive, due to the flat spectrum of the black pigments. 
Fig. 5. Neo-Attic bell crater with Waffentanzer (inv. 71406)

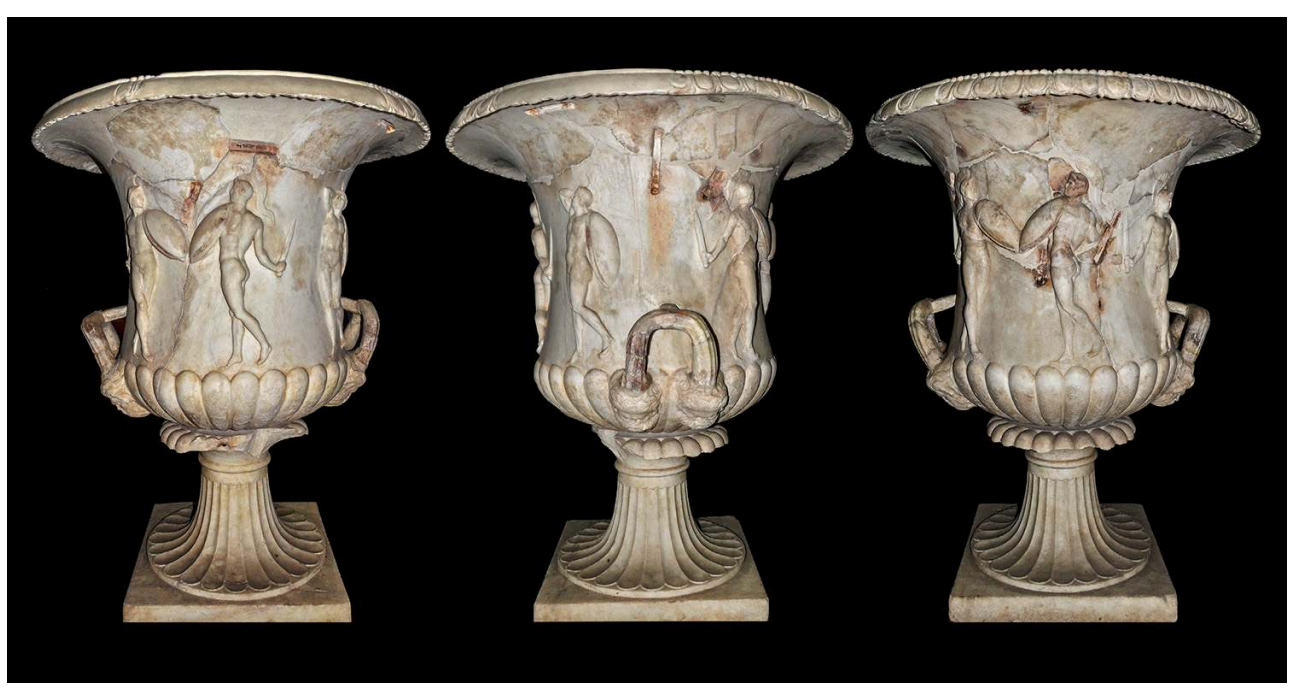

(C) ICVBC-CNR.

Fig. 6. Details of warriors' shields

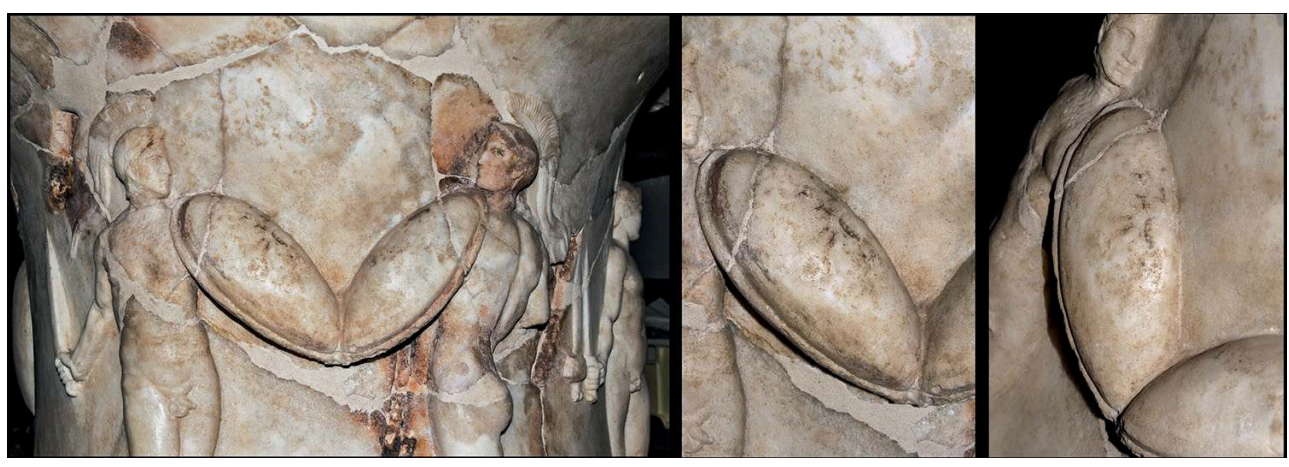

(C) ICVBC-CNR.

24 On the ensemble of the surface of the crater different red hues are still visible with various yellow areas. The different hues of red are not due to shades of the same colour but to the use of two different pigments. The dark red hue is cinnabar and it was used especially on the edge of the shields as proven by the XRF spectra in those points. The eyes of the dancers and other details are painted by using ochre. In this case it was quite impossible to reach the areas with the XRF instrument but the FORS spectra are sufficiently clear to be confident of the result.

25 Thanks to the strong luminescence of Egyptian blue, even the few crystals preserved on the crest of one of the dancer's helmet are visible. VIL also enhanced the triangle decoration on the same helmet due to the black response obtained (fig. 7). The previous attempts to recognise this decorative pattern with ultraviolet fluorescence had failed due to the presence of a red iron based patina all over the area. Also two swords show the presence of blue traces and VIL confirms the presence of Egyptian blue. 
Fig. 7. VIL detail of decorative pattern on the helmet

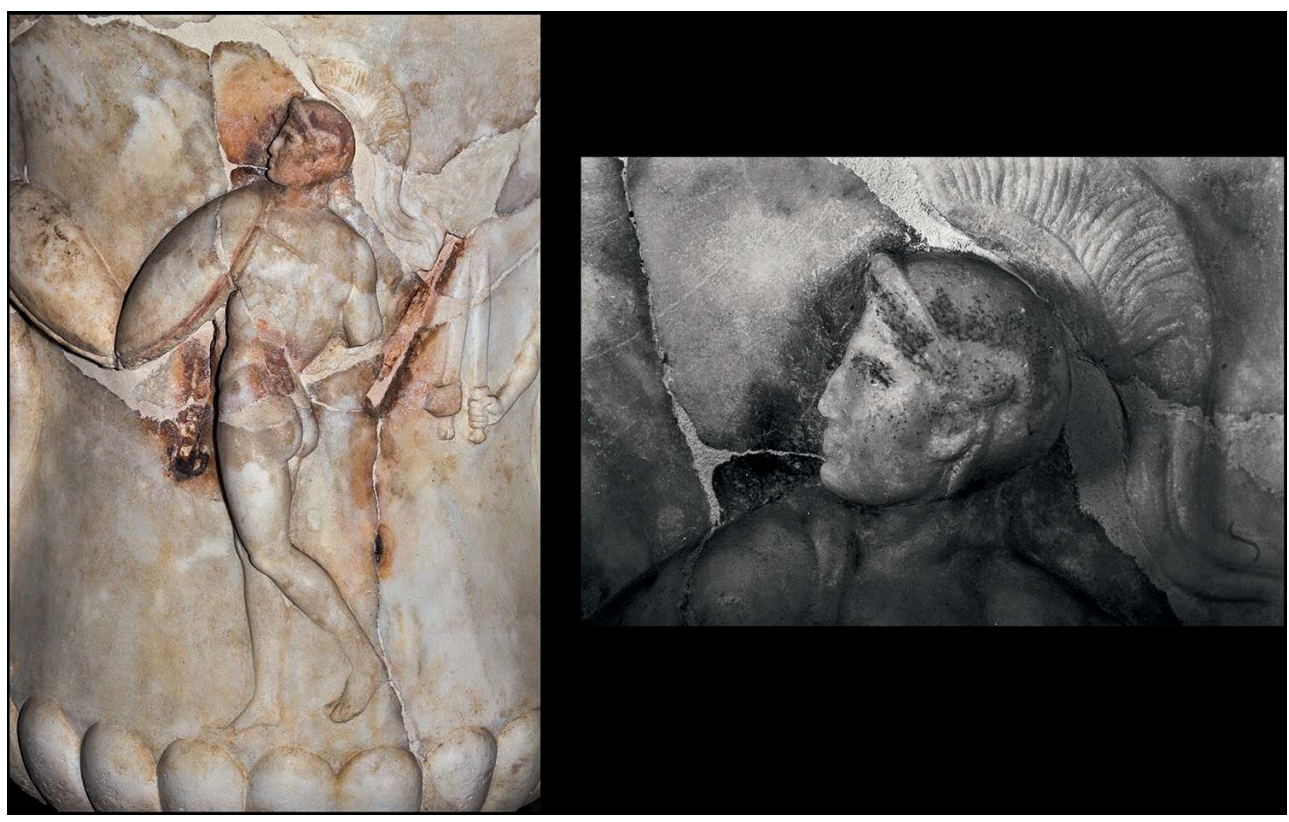

(c) ICVBC-CNR,

The inscription on a fragment of marble slab shows the presence of a substance that appears as bright yellow in ultraviolet fluorescence, and it seems identical to the fluorescence already observed on the mantle of the Ephebe. Unfortunately, in the inscription, the substance was in the internal part of the carved inscription, therefore only FORS could reach the material but notwithstanding this, no indications were obtained. At the same time, FORS spectra allowed to recognise in the red pigment the use of cinnabar, as already attested on the Ephebe (fig. 8 a-c). 
Fig. 8 a-c. Fragment of a marble slab with inscription (inv. 72791)
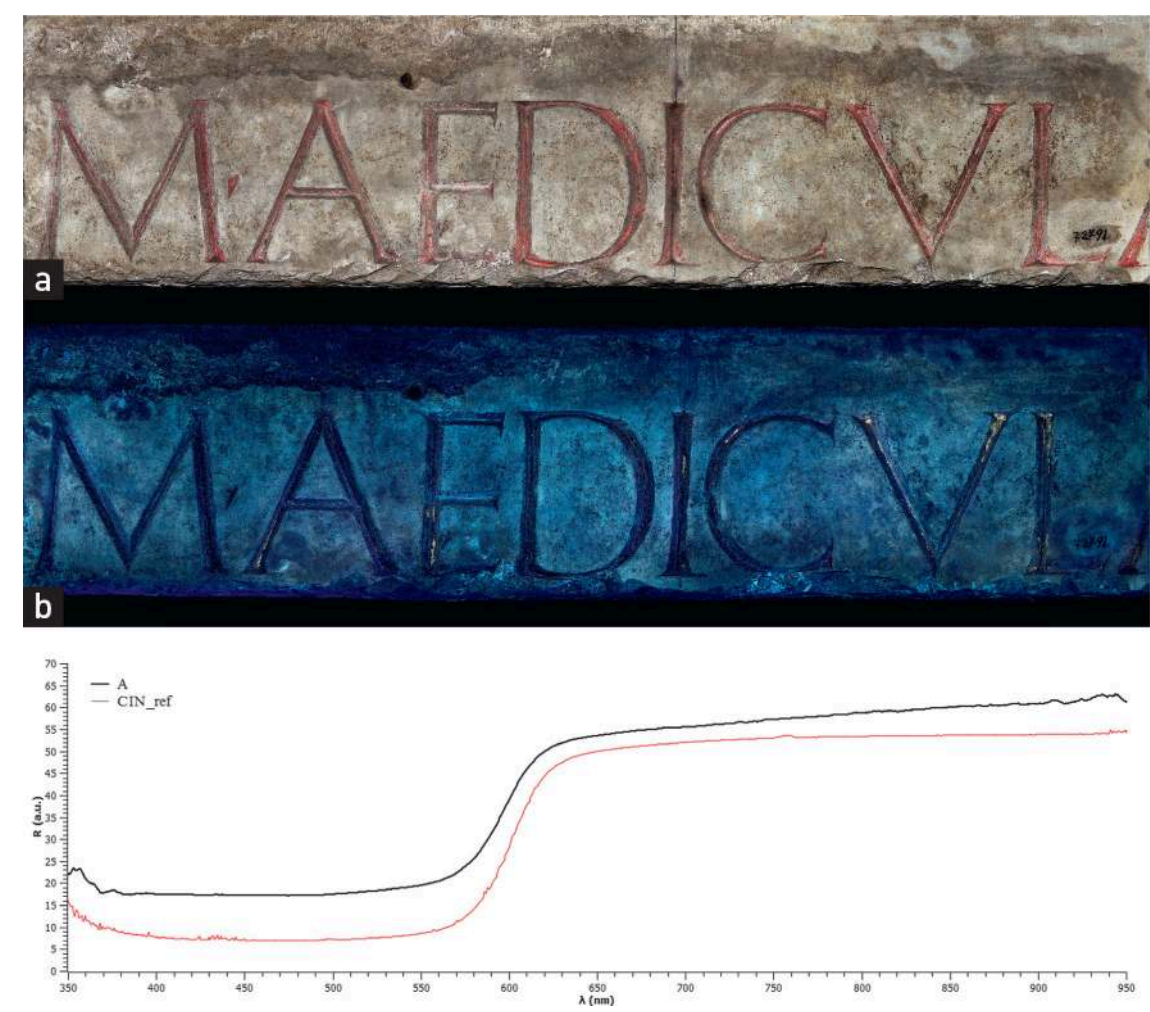

a. Visible image; b. UVf image; c. FORS spectrum of measured point on A compared with a reference spectrum of cinnabar.

(C) ICVBC-CNR.

During the analytical campaign, we also analysed a small crab covered by a thick layer of lime deposits. On the VIL images, it is possible to observe few small spots of Egyptian blue on the base, while ultraviolet fluorescence helped enhancing the stripes on the chest.

Even then no XRF measures have been possible due to the lime deposits, which have produced a rough surface and consequently a low X-rays count on sensor. The FORS measurements show the presence mainly of a mixture of iron oxide/hydroxide on the carapace as a base, while in some areas and on the stripes, it seems that cinnabar was mixed or superimposed with a red earth.

The last piece analysed in the depository is the portrait of a boy, but nothing was found except for some stain on the neck already visible to naked eyes.

A week before the Round Table in Paris, the statue of Satyr and Hermaphrodite came back from an exhibition in New York ${ }^{28}$ and on a visual recognition the curators mentioned the presence of traces of polychromy on the rock. Some preliminary analyses have been done but, as the statue was still packaged at the time, not all sides were available for analysis. An ultraviolet fluorescence examination produced no decisive information on some red traces on the rock at the base. Some interesting data have emerged with VIL. Both side of the rock below the Satyr show the presence of Egyptian blue. These traces were documented also with the microscope. In the microscopic images, both red and blue pigments are visible in the same area. Some hypotheses have been done about the co-presence of those pigments, but to confirm them, more analyses and researches must be carried out (fig. 9). 
Fig. 9.

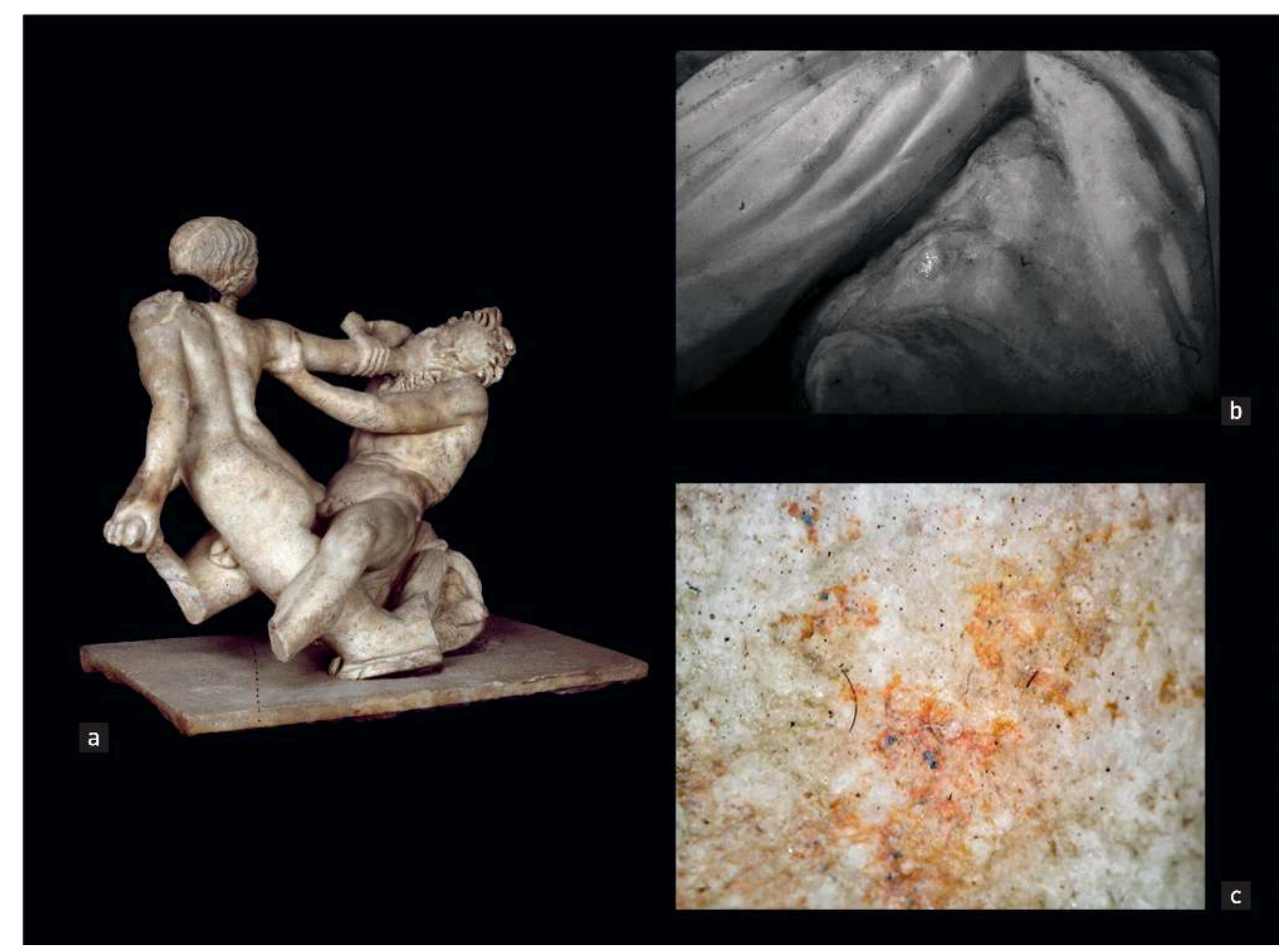

a. Satyr and Hermaphrodite (inv. 72800). @ Parco Archeologico di Pompei; b. VIL details; c. High magnification image (55x). (c) ICVBC-CNR.

\section{Conclusions}

31 In 1987, De Caro could see some colours which are still visible on the sculptures from Oplontis. However, some other traces are now lost (for example, the radiating crown on the dancers' shields, on the crater) and, in the course of our study, new evidence, not described by this previous author, has been detected (such as the blue colour on the Nike's himation ${ }^{29}$.

Some marble sculptures (Boy with a duck, the Centaurs, the portrait of a boy) present very few or no remains of colour traces, but other sculptures in Oplontis gave much more results. On the crater ${ }^{30}$, in particular, a yellow ochre was used for the hair of one of the dancing warriors. The red of the shields (cinnabar, in this case) and the helmets recalls the colours of the "Alexander Sarcophagus" from Sidon ${ }^{31}$. Traces of Egyptian blue were found on some swords ${ }^{32}$ and on one of the helmets' crest. One of the helmets presents a decorative motif with triangles, not visible to the naked eye.

There is another case of Neo-Attic bell crater with traces of original polychromy: the so-called "Medici Vase", at the Uffizi Galleries. The Uffizi crater arrived in Florence from Rome at the end of the 18th century and shows traces of the original colours and gilding ${ }^{33}$ : gold leaf on clothes and architectural elements, and some traces of blue, green, yellow and red (cinnabar and hematite $\left.{ }^{34}\right)$. 

two different colours in the same place: red and blue. At this stage, it is not clear if the blue was mixed with the red colour, in order to get a darker brown final aspect (for the rock in particular), or if the red was superimposed on blue. A red layer with a superimposed blue layer was found on a cuirassed statue from Tarragona ${ }^{35}$, while a blue layer with a superimposed red layer is visible on the garments of a Mithras' sculpture from the Kircher Museum ${ }^{36}$. The blue colour could be part of a decorative motif on the Ephebe's mantle, and a background colour for the rock ${ }^{37}$. But the results are too preliminary at this point to decide which could be the original appearance of these sculptures.

The authors wish to thank the Parco Archeologico di Pompei, the Director Prof. Massimo Osanna and all the staff of the Oplontis - Villa A archaeological site.

\section{BIBLIOGRAPHY}

Brinkmann V., 2004, “Gli occhi azzurri dei persiani. La scultura policroma dell'età di Alessandro e dell'Ellenismo", in P. Liverani (ed.), I colori del bianco. Policromia nella scultura antica, De Luca Editori d'Arte, Roma, p. 209-224.

Brinkmann V., Koch-Brinkmann U., 2010, "On the reconstruction of antique polychromy techniques”, in V. Brinkmann, O. Primavesi, M. Hollein (eds.), Circumlitio. The Polychromy of Antique and Mediaeval Sculpture, Frankfurt am Main 10-12 December 2008, Liebieghaus Skulpturensammlung, Frankfurt am Main, p. 114-135.

De Caro S., 1987, “The sculptures of the Villa of Poppaea at Oplontis: A Preliminary Report”, in E. Blair MacDougall (ed.), Ancient Roman Villa Gardens, Dumbarton Oaks Colloquium on the History of Lanscape Architecture, 10th; 1984, Dumbarton Oaks Research Library and Collection, Washington D.C., p. 77-133.

Gazda E. K., Naglak M. C., 2016, "Mutable meanings in the sculpture from Villa A", in E. K. Gazda, J. R. Clarke (eds.), Leisure and Luxury in the age of Nero. The villas of Oplontis near Pompeii, Kelsey Museum Publication 14, Ann Arbor, Michigan, p. 136-147.

Grassinger D., 1991, Römische Marmorkratere, Philipp von Zabern, Mainz am Rhein.

Iannaccone R., Bracci S., Cantisani E., Mazzei B., 2015, “An integrated multimethodological approach for characterizing the materials and pigments on a sarcophagus in St. Mark, Marcellian and Damasus catacombs", Applied Physics A 121, p. 1235-1242.

Jashemski W., 1987, "Recently excavated gardens and cultivated land of the Villas at Boscoreale and Oplontis", in E. Blair MacDougall (ed.), Ancient Roman Villa Gardens, Dumbarton Oaks Colloquium of the History of Landscape Architecture, 10th; 1984, Dumbarton Oaks Research Library and Collection, Washington D.C., p. 31-76. 
Koppel E. M., 1985, Die römischen Skulpturen von Tarraco, De Gruyter, Berlin.

Liverani P., 2014, “Per una 'Storia del colore'. La scultura policroma romana, un bilancio e qualche prospettiva", in P. Liverani, U. Santamaria (eds.), Diversamente bianco. La policromia della scultura romana, Edizioni Quasar, Roma, p. 9-32.

Manna D., Rossi A., 2018, “Il Vaso Medici. Il restauro (2016-2017)”, in E. Bazzechi, C. Parigi (eds.), Un'anima grande e posata. Studi in memoria di Vincenzo Saladino offerti dai suoi allievi, Scienze e Lettere, Roma, p. 193-202.

Moormann E. M., 2016, “Standing Artemis/Diana”, in E. K. Gazda, J. R. Clarke (eds.), Leisure and Luxury in the age of Nero. The villas of Oplontis near Pompeii, Kelsey Museum Publication 14, Ann Arbor, Michigan, p. 194, n. 31.

Moormann E. M., 2019, "Marble sculptures and architectural elements”, in J. R. Clarke, N. K. Muntasser (eds.), Oplontis, Villa A ("of Poppaea") at Torre Annunziata, Italy. Volume 2. The Decorations: Painting, Stucco, Pavements, Sculptures, ACLS Humanities E-Book, New York, p. 1249-1810.

Paolucci F., 2018, “'Ansas amplexus acantho'. Alcune osservazioni sul Vaso Medici restaurato”, in E. Bazzechi, C. Parigi (eds.), Un'anima grande e posata. Studi in memoria di Vincenzo Saladino offerti dai suoi allievi, Scienze e Lettere, Roma, p. 173-192.

Simeone C., 2001, "Un femminile indistinto. Le centaure di Oplonti”, in F. Senatore (eds.), Pompei tra Sorrento e Sarno. Atti del terzo e quarto ciclo di conferenze di geologia, storia e archeologia. Pompei, gennaio 1999-maggio 2000, Bardi Editore, Roma, p. 147-163.

\section{NOTES}

1. I want to thank Dr. Stefano De Caro for having shared his unpublished research about Oplontis with me. The references to the old excavations and more come from one of his forthcoming papers [A. B.].

2. See note $n$. 1 .

3. Jashemski, 1987.

4. De Caro, 1987.

5. Gazda, Naglak, 2016, p. 142.

6. Moormann, 2016, p. 194.

7. De Caro, 1987, p. 112.

8. Gazda, Naglak, 2016, p. 145.

9. Ov., Met. 10, p. 560-707.

10. De Caro, 1987, passim.

11. De Caro, 1987, p. 96, n. 11: "Remnants of color are still visible [...] on the radiating crown decorating the center of the shields (gold)."

12. De Caro, 1987, p. 114, n. 20: "yellow on the hair of the goddess and of the Eros; red on the sandals and on the cloak of Eros."

13. De Caro, 1987, p. 116, n. 22.

14. The Venus was in the United States during this first campaign, as well as many other sculptures (see note n. 25).

15. Inv. no. 70056. De Caro, 1987, p. 94-97, n. 9; Moormann, 2019, p. 1305-1312, n. 9.

16. Inv. no. 73520. De Caro, 1987, p. 108-110, n. 17; Moormann, 2019, p. 1266-1274, n. 4.

17. Inv. no. 72818. De Caro, 1987, p. 104-106, n. 15; Moormann, 2019, p. 1295-1304, n. 8.

18. Inv. no. 71406. De Caro, 1987, p. 96-98, n. 11; Moormann, 2019, p. 1478-1485, n. 62. 
19. Inv. nos. 70070 (male) and 70071 (female). De Caro, 1987, p. 88-89, nos. 1 and 3; Simeone, 2001; Moormann, 2019, p. 1336-1343, n. 14, p. 1326-1329, n. 12.

20. Inv. no. 73299. De Caro, 1987, p. 112-113, n. 19; Moormann, 2019, p. 1390-1394, n. 26.

21. Inv. no. 72800. De Caro, 1987, p. 98-101, n. 12; Moormann, 2019, p. 1313-1319, n. 10.

22. Inv. no. 72791. De Caro, 1987, p. 124, n. 43.

23. Inv. no. 71517. De Caro, 1987, p. 116, n. 22; Moormann, 2019, p. 1435-1439, n. 40.

24. Iannaccone et al., 2015.

25. During the first campaign, in 2016, most of the sculptures were in the United States for an exhibition: these marbles are often moved to new exhibitions and it is very difficult to find the entire complex in the storage. Recently, new analyses were carried out on the sculptures that were in the United States in 2016. The results of the new campaign will be the topic of a forthcoming monograph about the sculptures from Villa A, edited by the university of Cologne.

26. The sculptures coming from the Villa A in Oplontis represent a very interesting complex group: they were buried all at the same time, during the Vesuvius' eruption. They were part of a unique context. For this reason, we think that it is important to publish also the negative results of the research about polychromy: the lack of polychromy can be related, in this case, with a faint colour of the sculpture yet before the eruption, or with after-finding factors, but not with the burial conditions (as some sculptures have kept a rich polychromy). It is thus important to study the complex as a whole and not each sculpture individually.

27. Iannaccone et al., 2015.

28. See note n. 26.

29. De Caro, 1987, p. 108, n. 17.

30. For a first description of its polychromy, see De Caro, 1987, p. 96, n. 11 and Grassinger, 1991, p. 218, n. 60 .

31. Brinkmann, 2004, p. 209-216; Brinkmann, Koch-Brinkmann, 2010, p. 120-125.

32. De Caro, 1987, p. 96, n. 11, records traces of blue for the swords. He also records the colour red for the helmets.

33. Paolucci, 2018, p. 179-180; Manna, Rossi, 2018. The gilding of the Medici Vase is superimposed to a layer of red bolus (Paolucci, 2018, p. 179).

34. The hematite is probably part of the bolus for the gilding (Paolucci, 2018, p. 179).

35. MNAT 45602: Koppel, 1985, p. 19-20, n. 10, pl. 7, 3; 8, 1-3.

36. Now Museo Nazionale Romano, inv. 85196. The polychromy of this sculpture of Mithras tauroctonos was part of the case-studies for the paper "Mithras' colours" (by

S. Bracci, R. Iannaccone, S. Lenzi, P. Liverani, D. Magrini, G. Bartolozzi), 9th Round Table on Polychromy in Ancient Sculpture and Architecture (British Museum, 9-10 November 2018).

37. About the blue used for backgrounds: Liverani, 2014, in particular.

\section{ABSTRACTS}

The so-called Villa of Poppaea in Oplontis (Torre Annunziata, Naples - also known as "Villa A") was destroyed after the Vesuvius' eruption in 79 A.D. It is nowadays one of the World Heritage Sites of UNESCO. The building, one of the richest in marble furnishing in the Roman world, was excavated mostly during the second half of the 20th century. In this paper, only part of the sculptures and reliefs were studied. The furnishing were analysed in situ by means of portable 
and totally non-invasive techniques. By comparing the results obtained through imaging techniques with analytical data and archaeological research, some new information about the pigments and conservation history were obtained.

La villa dite de Poppée à Oplontis (actuelle Torre Annunziata), également connue sous l'appellation de villa A, fut ensevelie sous les cendres du Vésuve en l'an 79. L'Unesco l'a inscrite sur la Liste du patrimoine mondial. C'est l'un des sites les plus riches en décors de marbre de tout le monde romain, mis au jour pour l'essentiel durant la seconde moitié du $\mathrm{xx}^{\mathrm{e}}$ siècle. Nous nous intéressons ici à une partie seulement des sculptures et des reliefs. Les œuvres ont fait l'objet d'une analyse in situ par des techniques mobiles et entièrement non-invasives. La comparaison des données fournies par les techniques d'imagerie avec les résultats des analyses et de la recherche archéologique a livré de nouvelles informations sur les pigments et sur l'état de conservation.

\section{INDEX}

Keywords: Oplontis, sculpture romaine, pigments, imagerie, polychromie, techniques noninvasives, XRF (analyse par fluorescence X), FORS (Spectrométrie par réflexion à l'aide de fibre optique)

Mots-clés: Oplontis, Roman sculpture, pigments, imaging, polychromy, non-invasive analyses, XRF (X-ray fluorescence spectroscopy), FORS (Fiber optics reflectance spectroscopy)

\section{AUTHORS}

\section{ANTONELLA BONINI}

Archaeologist, Parco Archeologico di Pompei (antonella.bonini[at]beniculturali.it).

\section{SUSANNA BRACCI}

Senior Researcher, ICVBC-CNR, Firenze (s.bracci[at]icvbc.cnr.it).

\section{PAOLO LIVERANI}

Professor, Università degli Studi di Firenze (paolo.liverani[at]unifi.it).

\section{GIOVANNI BARTOLOZZI}

Researcher, IFAC-CNR, Firenze (g.bartolozzi[at]ifac.cnr.it).

\section{ROBERTA IANNACCONE}

Researcher, ICVBC-CNR, Firenze (robertaiannaccone[at]hotmail.com).

\section{SARA LENZI}

Independent Researcher (sara.lenzi2014[at]gmail.com).

\section{DONATA MAGRINI}

Researcher, ICVBC-CNR, Firenze (donata.magrini[at]cnr.it). 